\title{
Analysis of growth of recruits of natural regeneration of Sorbus torminalis (L.) Crantz - a rare European forest tree species
}

\author{
Leszek Bednorz, \\ Renata Nowinska
}

\section{Introduction}

The wild service tree Sorbus torminalis (L.) Crantz is a typical rare forest species with a scattered distribution (Rasmussen \& Kollmann 2004). It is distributed across western, central and southern Europe, but also occurs in south-western Asia and north-western Africa. The species is a minor component of various oak and some times beech or pine-dominated forests, where it is usually found at low density (<30 trees ha ${ }^{-1}$ - Demesure-Musch \& Oddou-Muratorio 2004) and only exceptionally occurs in considerable densities (Müller et al. 2000, Hochbichler 2003, Pyttel et al. 2013).

The wild service tree forms fleshy, brown fruits, dispersed by birds and small mammals (Oddou-Muratorio et al. 2004, Rasmussen \& Kollmann 2004, Rich et al. 2010,

\begin{abstract}
We compared growth and survival of wild service tree (Sorbus torminalis [L.] Crantz) recruits of different origin (generative: seedlings; vegetative: root suckers) established in a fenced plot at the Forest District of Krzyz (northwestern Poland). Total height, annual growth of the dominant shoot, stem diameter at root collar, number of first-order branches, and mortality were measured every year over the period 2011-2015 (5 years). In 2011, a total of 382 multi-age recruits originated both from seeds (212) and root suckers (170) were recorded. Five-year mortality was higher in the generative progeny (12.3\% - only youngest seedlings) as compared with vegetative recruits $(2.9 \%)$. The growth rate of individuals markedly increased with height as absolute values, but slightly decreased in terms of relative growth. Statistical analysis revealed that the effect of the recruit origin on growth was noticeably weaker than that of age, defined in terms of development (height) classes. The origin of recruits had a major effect on the annual growth of the dominant shoots and a minor (though significant) effect on stem diameter and the number of first-order branches. Overall, the analysis of growth rate showed that generative recruits grow faster than the vegetative ones. Our results highlight the importance of stimulating the generative regeneration and protecting seedlings as a conservation strategy for Sorbus torminalis.
\end{abstract}

Keywords: Sorbus torminalis, Regeneration, Growth, Mortality, Seedlings, Root Suckers
Pyttel et al. 2013). It reproduces both by seeds and root suckers, the latter especially at the distribution border in northeastern Europe (Hoebee et al. 2006, Rasmussen \& Kollmann 2007, Rasmussen \& Kollmann 2008, Rich et al. 2010, Jankowska-Wroblewska et al. 2016). However, abundant regeneration by root suckers has also been observed in the centre of the species distribution, in Switzerland (Rotach 2000) and in Germany (Ewald et al. 1994, Schüte 2001, Pyttel et al. 2013). The recruits are often browsed by deer, so their protection by fencing is recommended (Nicolescu et al. 2009, Bednorz et al. 2012). Vegetative reproduction could be particularly important under circumstances where natural growth of forest trees is difficult, e.g., near the distribution limit of the species, in dynamic habitats or under heavy shade
Department of Botany, Poznan University of Life Sciences, Wojska Polskiego 71C, 60-625 Poznan (Poland)

@ Leszek Bednorz (lbednorz@up.poznan.pl)

Received: Jan 04, 2017 - Accepted: Oct 25, 2017

Citation: Bednorz L, Nowinska R (2018). Analysis of growth of recruits of natural regeneration of Sorbus torminalis (L.) Crantz - a rare European forest tree species. iForest 11: 72-78. - doi: 10.3832/ifor2347-010 [online 2018-01-25]

Communicated by: Emanuele Lingua
(Koop 1987). Furthermore, in case of Sorbus torminalis, root suckering may sometimes be the only possible way to reproduce and survive.

The wild service tree is often considered a light-demanding/semi-shade species, often out-competed by other hardwood species (Hochbichler 2003, Demesure-Musch \& Oddou-Muratorio 2004, Bednorz 2007, 2009 Paganova 2007). On the other hand, some observations and studies show that the species is shade tolerant and can persist for many years under the canopy of other deciduous trees (Pyttel et al. 2013).

In Poland, Sorbus torminalis occurs rarely in deciduous and mixed forests in its western and southern part and the species has been protected by law since 1946. Recently, active protection measures have been implemented in Polish state forests to preserve this species. Initiation of natural regeneration and protection of recruits against browsing damage are among the basic tools of active protection of natural populations of the wild service tree (Bednorz 2007, 2009, Bednorz et al. 2012).

Although knowledge of the development of natural regeneration is essential for properly planning conservation activities, there are no studies comparing the growth and survival of Sorbus torminalis recruits originated from seeds and root suckers in natural populations. Several studies investigated the growth and survival rate of wild service tree seedlings cultivated in nurs- 
eries or progeny-provenance plots (Espahbodi et al. 2008, Sulkowska \& Wojda 2015), but no data are available so far on the spontaneous regeneration of such species in the forest, with the exception of Schüte (2001) who investigated the growth and shade tolerance of root suckers in a natural population in Germany.

In this study, we analysed the survival and growth of Sorbus torminalis recruits (both root suckers and originated from seeds) in the Forest District of Krzyz (north-western Poland). Fenced plots were established in the forest to investigate offspring under conditions of releasing from browsing and limitation of competition from hornbeam seedlings. We addressed the following questions: (1) does the survival rate of $S$. torminalis recruits depend on their age (expressed as age-related development classes of offspring) and origin (seedlings and root suckers)? (2) To what extent the growth rate of $S$. torminalis recruits does depend on their age and origin?

\section{Materials and methods}

\section{Study area}

The wild service tree occurs in only one site at the Forest District of Krzyz, namely in the moraine upland of the Drawa Valley, within the area of the Debina Forestry. The study area is a deciduous mesic forest habitat on cambisoils, represented by a lowdensity seed stand of pedunculate oak with scant admixture of hornbeam and beech. This forest is not under legal protection. The average annual precipitation in the region is approximately $544 \mathrm{~mm}$ and the annual average temperature amounts to $8.4{ }^{\circ} \mathrm{C}$ (Wos 2010).

The local population of Sorbus torminalis comprises 23 adult trees and quite numerous recruits of natural regeneration. In spring 2011, lots of new seedlings were found in forest compartment $295\left(52^{\circ} 57^{\prime}\right.$ $36.9^{\prime \prime} \mathrm{N}, 15^{\circ} 58^{\prime} 38.3^{\prime \prime} \mathrm{E}$; elevation $64 \mathrm{~m}$ a.s.l.), Three plots with abundant offspring were fenced to protect the recruits against browsing by deer. Moreover, hornbeam seedlings overgrowing Sorbus torminalis recruits were removed once a year by the local forest service.

\section{Data collection}

Data was collected within the largest plot (0.41 ha), which was chosen for the detailed study for two reasons: (i) because of the large number of recruits originated both from seeds and root suckers; (ii) because the light regime (semi-shade) was approximately the same for all recruits over the plot. All the individuals of S. torminalis within the plot were mapped using an electronic tachymeter GTS-229 ${ }^{\circledR}$ (Topcon Ltd., Singapore). Each recruit was provided with label and sequential number. Three adult trees of the species growing within the fenced plot were also mapped. The plot was monitored each autumn since 2011. During the five subsequent years (2011-2015), each of the recruits were measured for the following characters: total height, annual growth of the dominant shoot, stem diameter at root collar and the total number of first order branches. Annual growth was defined as the length between the scars left on the stem by the last winter buds and the stem top. As we were not able to clearly pinpoint the age of recruits, we used age-development classes expressed in terms of offspring height (see "Data analysis"). In the case of seedlings, their initial age (in 2011) was estimated based on counting the height annual increments (about 1-10 years). Although we do not have knowledge about browsing episodes before fencing the plot in 2011, we have noted very few damaged specimens in the first year of observations.
Fig. 1 - Spatial distribution of Sorbus torminalis generative $(1$, red squares) and vegetative (2, green circles) recruits within the experimental plot; (3): adult wild service trees; (4): fence.

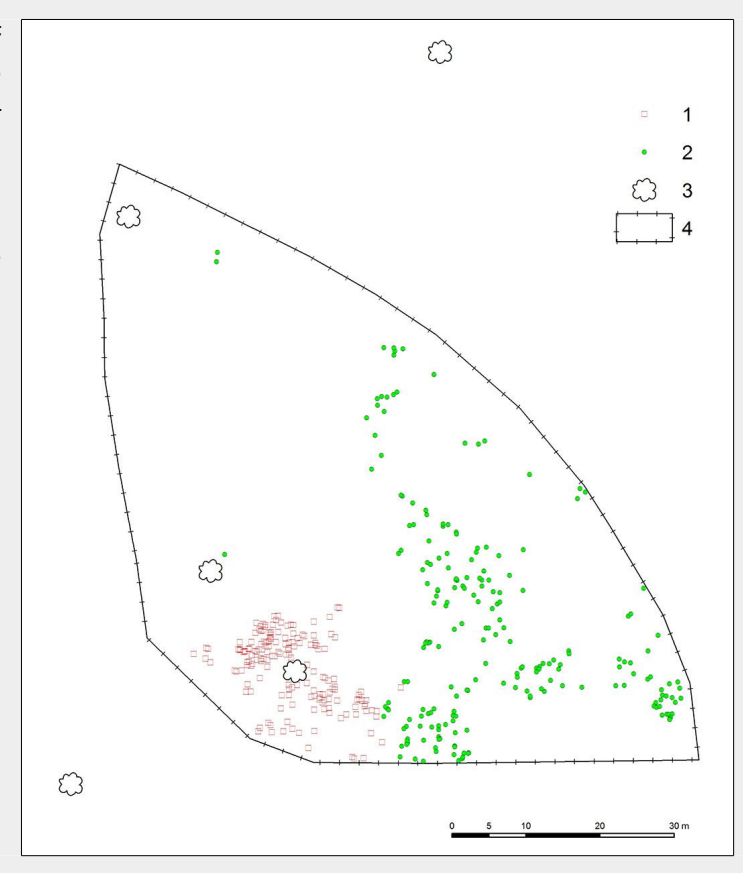

Moreover, the architecture of suckers did not suggest any former intensive grazing.

\section{Data analysis}

In order to analyse the effects of origin and age on the mortality and growth of Sorbus torminalis recruits, the individuals were separated into two categories: generative progenies (seedlings) and vegetative progenies (suckers) and into four age-development classes based on their total height: $(\mathrm{Cl})$ up to $15 \mathrm{~cm}$; $(\mathrm{CII}): 16-49 \mathrm{~cm}$; (CIII): $50-79 \mathrm{~cm}$; (CIV): over $79 \mathrm{~cm}$. The origin of recruits was determined on the basis of morphological features, mode of distribution and supported by a genetic analysis performed on the sample of 66 individuals (Burczyk J \& Jankowska-Wroblewska S unpublished data).

To analyse how the population of recruits changed over time, the mortality of vegetative and generative progenies over the five years was determined, together with the distribution of specimens in the different age-development classes in 2011 and 2015.

All analyses that concerned plant growth were based on the age-development classification carried out in 2011. First, multivariate and variate analyses of variance (MANOVA and ANOVA, respectively) were performed to compare the size of progenies of different age-development classes in the first and last years of observations. Next, hierachical multiple regression was used to estimate differences in growth rate among progenies of different age and origin. The age-development classes were used as the main predictor (model M1), and then the origin categories were included in the model (model M2). Statistical analysis were carried out including all the measured variables (annual growth, stem diameter and number of first order branches), except total height which was used to establish agedevelopment classes and therefore excluded from both MANOVA and regression analyses. Annual differences between individuals of different origin and age were tested using a $t$-test. Prior to the statistical analyses all the variables were log-transformed to better approximate normality and homogeneity. Because some of the variables had a value of 0 , the transformation was done according to the formula $x=$ $\log (x+1)$. In MANOVA/ANOVA and regression analysis, the homoscedasticity was tested on scatter plots between the predictors and the residuals. Charts included in the paper show real (untransformed) values. All statistical analyses were carried out using STATISTICA ${ }^{\circledast}$ ver. 12 (StatSoft, Tulsa, OK, USA) and SPSS ${ }^{\circledast}$ ver. 19 (IBM Corp., Harmonk, NY, USA).

\section{Results}

\section{Regeneration structure}

Overall, 382 multiage recruits of Sorbus torminalis originating both from seeds and root suckers were recorded in 2011, of 
which 212 were generative and 170 vegetative progenies (Fig. 1).

The number of individuals decreased to 313 in the subsequent five years: 31 died, 36 were missing and 2 were damaged. Fiveyear mortality was clearly higher in the generative progeny ( 26 specimens, ca. $12 \%$ ) as compared to vegetative one ( 5 specimens, ca. 3\% - see Fig. 2). All dead generative individuals were seedlings belonging to the age-development class $\mathrm{Cl}$, while dead vegetative recruits were from classes $\mathrm{Cl}, \mathrm{CII}$ and CIII.

The age-development pyramid changed between 2011 and 2015. In the first year of the study, $\mathrm{Cl}$ individuals dominated in the generative and CIl among the vegetative progeny. CIV individuals were not observed. In 2015 all four age-development classes were observed and their share was more evenly distributed (Fig. 3).

Growth rate of recruits of different age Individuals that belonged to different age-development classes in 2011 differed significantly four years later (2011: MANOVA Wilk's $\lambda=0.39, F_{[6 ; 616]}=62.62, p<0.0001$; 2015: MANOVA Wilk's $\lambda=0.55, F_{[6 ; 616]}=35.46$, $\mathrm{p}<0.0001)$. individuals of different age differed for all the tested variables (ANOVA, $\mathrm{p}<0.0001)$. The growth rate of recruits increases markedly with age, when we compare the direct values of the characters (Fig. 4), and slightly decreases when the relative growth is considered (Fig. 5).

\section{Growth rate of recruits of different age} and origin

According to hierarchical multiple regression, age-development classes accounted for $20-32 \%$ of the variability in the growth of recruits. The predictor was highly significant in all derived M1 models $(p<0.000)$. When the origin of recruits was included in the model ( $M 2$ models), the total explained variance slightly increased to $21-33 \%$ (Tab. 1). The impact of the origin of recruits on their growth was noticeably weaker $(\beta<0.1)$ than the impact of the age-development class $(\beta>0.5)$. The origin of recruits had a major effect on the annual growth of shoots $(\beta=-0.09 ; t=-3.67 ; p<0.01)$, as well as a minor (though significant) effect on the number of branches $(\beta=-0.06 ; t=-2.59$; $\mathrm{p}=0.01)$ and stem diameter $(\beta=-0.05 ; t=-$ 2.08; $p=0.04$ - see Tab. 2 ).

In the first year of the study, vegetative individuals from $\mathrm{Cl}$ and $\mathrm{Cll}$ classes were significantly taller, showed greater annual growth and had thicker stem diameter (only $\mathrm{Cl}$ ) as compared to generative ones ( $t$-test, $0.0001<\mathrm{p}<0.05$ ). There were no significant differences in the number of lateral branches of suckers and seedlings from $\mathrm{Cl}$ and CII groups. In 2011, the CIII root suckers and seedlings did not differ in any of studied variables. Over the next four years, the growth rate was higher for generative individuals. In 2015, the seedlings that had previously been classified as $\mathrm{Cl}$ had smaller stem diameter as compared to vegetative
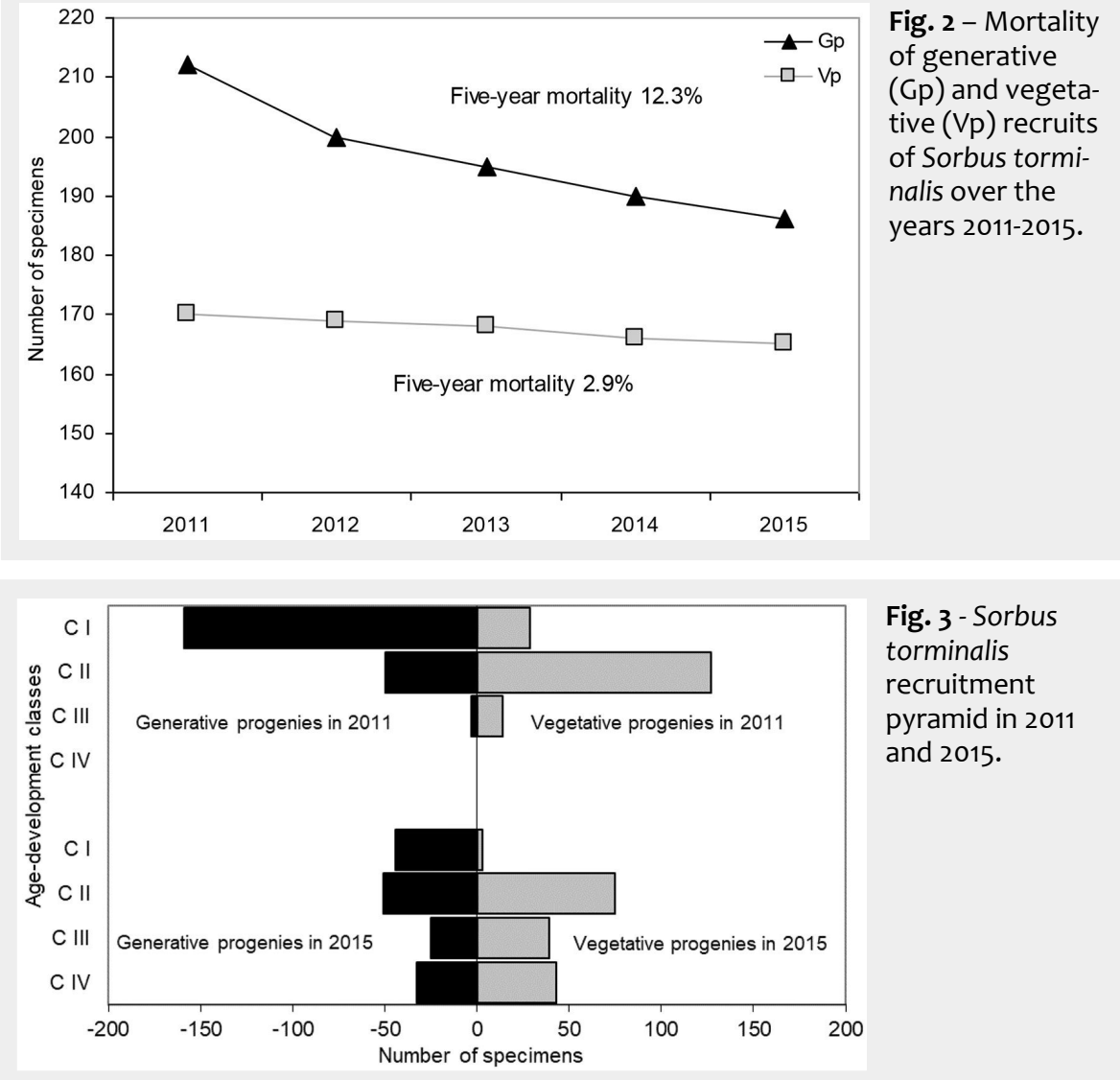

Fig. 3 - Sorbus torminalis recruitment pyramid in 2011 and 2015.

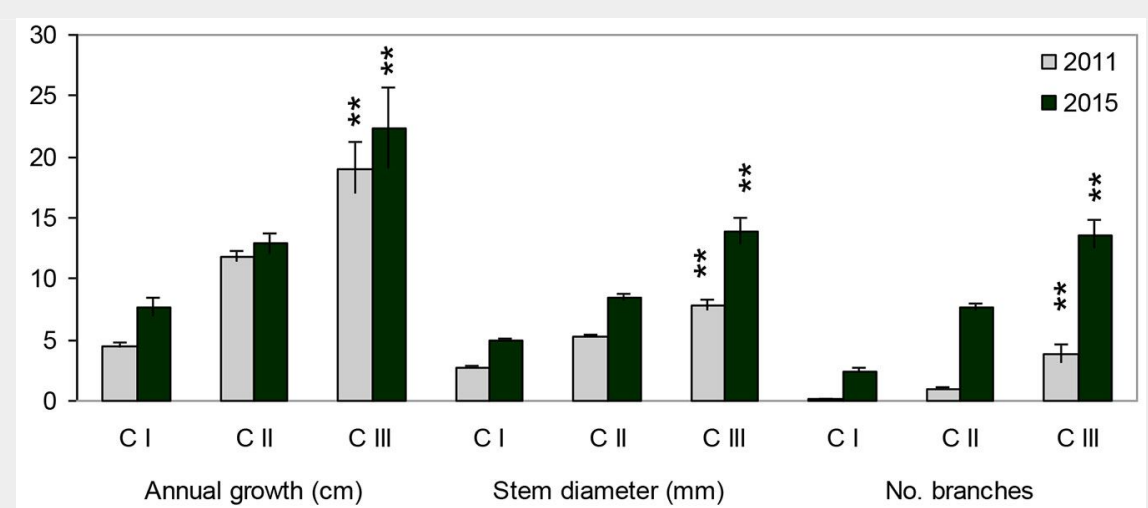

Fig. 4 - Mean values of height growth in individuals belonging to different age-development classes (development classes by the state for the year 2011). Asterisks indicate significant differences $(p<0.001)$ among classes in 2011 and 2015 after ANOVA. Error bars represent the standard error.

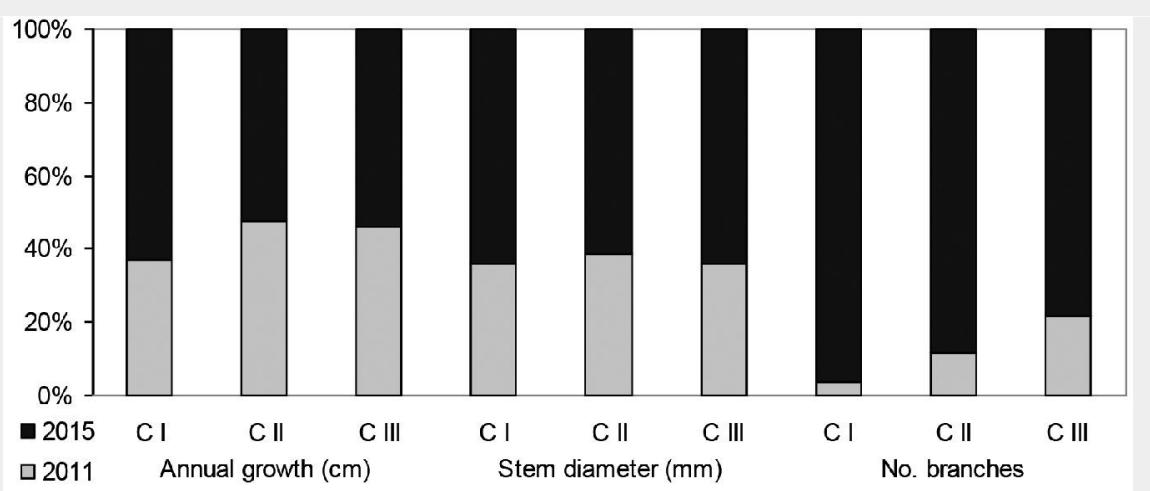

Fig. 5 - Relative values of growth characteristics in individuals belonging to different age-development classes (development classes by the state for the year 2011). 
Tab. 1 - Summary of the hierarchical multiple regression of the age-development classes and origin on Sorbus torminalis recruits growth. (a) M1 predictors: (Constant), age-development classes by the state for the year 2011; M2 predictors: (Constant), age-development classes by the state for the year 2011, origin. (SE): standard error; (df): degrees of freedom.

\begin{tabular}{|c|c|c|c|c|c|c|c|c|}
\hline $\begin{array}{l}\text { Dependent } \\
\text { variable }\end{array}$ & Model $^{(a)}$ & $\mathbf{R}^{2}$ & Adj- $R^{2}$ & $\begin{array}{c}\text { SE } \\
\text { estimate }\end{array}$ & $\mathbf{R}^{2}$ & $\mathbf{F}$ & df & Prob. \\
\hline \multirow[t]{2}{*}{ Annual growth } & M1 & 0.204 & 0.203 & 8.713 & 0.204 & 400.271 & $1 ; 1563$ & $<0.001$ \\
\hline & M2 & 0.211 & 0.210 & 8.679 & 0.007 & 13.476 & $1 ; 1562$ & $<0.001$ \\
\hline \multirow[t]{2}{*}{ Stem diameter } & M1 & 0.322 & 0.321 & 2.637 & 0.322 & 741.823 & 1;1563 & $<0.001$ \\
\hline & $M 2$ & 0.326 & 0.325 & 2.634 & 0.002 & 4.341 & $1 ; 1562$ & 0.037 \\
\hline \multirow[t]{2}{*}{ No. branches } & M1 & 0.283 & 0.283 & 3.381 & 0.283 & 618.174 & 1;1563 & $<0.001$ \\
\hline & $M 2$ & 0.286 & 0.286 & 3.375 & 0.003 & 6.691 & $1 ; 1562$ & 0.010 \\
\hline
\end{tabular}

Tab. 2 - Coefficients of the hierarchical multiple regression of the age-development classes and origin on Sorbus torminalis recruits growth. Age-development classes by the state for the year 2011.

\begin{tabular}{|c|c|c|c|c|c|c|}
\hline \multirow{2}{*}{$\begin{array}{l}\text { Dependent } \\
\text { variable }\end{array}$} & \multirow[t]{2}{*}{ Predictors } & \multicolumn{2}{|c|}{$\begin{array}{c}\text { Unstandardized } \\
\text { coefficients }\end{array}$} & \multirow{2}{*}{$\begin{array}{c}\text { Standardized } \\
\text { coefficients } \\
\text { Beta }\end{array}$} & \multirow[t]{2}{*}{$\mathrm{t}$} & \multirow[t]{2}{*}{ p-value } \\
\hline & & B & SE & & & \\
\hline \multirow[t]{3}{*}{ Annual growth } & constant & -1.977 & 0.669 & - & -2.954 & 0.003 \\
\hline & age-dev. class & 8.435 & 0.437 & 0.498 & 19.302 & $<0.001$ \\
\hline & origin & -1.849 & 0.504 & -0.095 & -3.671 & $<0.001$ \\
\hline \multirow[t]{2}{*}{ Stem diameter } & constant & 0.733 & 0.203 & - & 3.610 & $<0.001$ \\
\hline & age-dev. class & 3.286 & 0.133 & 0.592 & 24.778 & $<0.001$ \\
\hline \multirow[t]{3}{*}{ No. branches } & constant & -2.436 & 0.260 & - & -9.361 & $<0.001$ \\
\hline & age-dev. class & 3.903 & 0.170 & 0.564 & 22.971 & $<0.001$ \\
\hline & origin & -0.507 & 0.196 & -0.063 & -2.587 & 0.010 \\
\hline
\end{tabular}
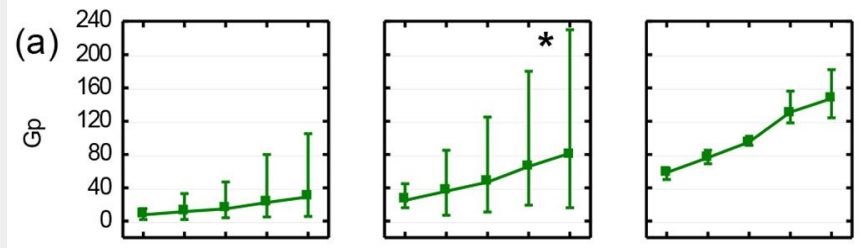

(b)
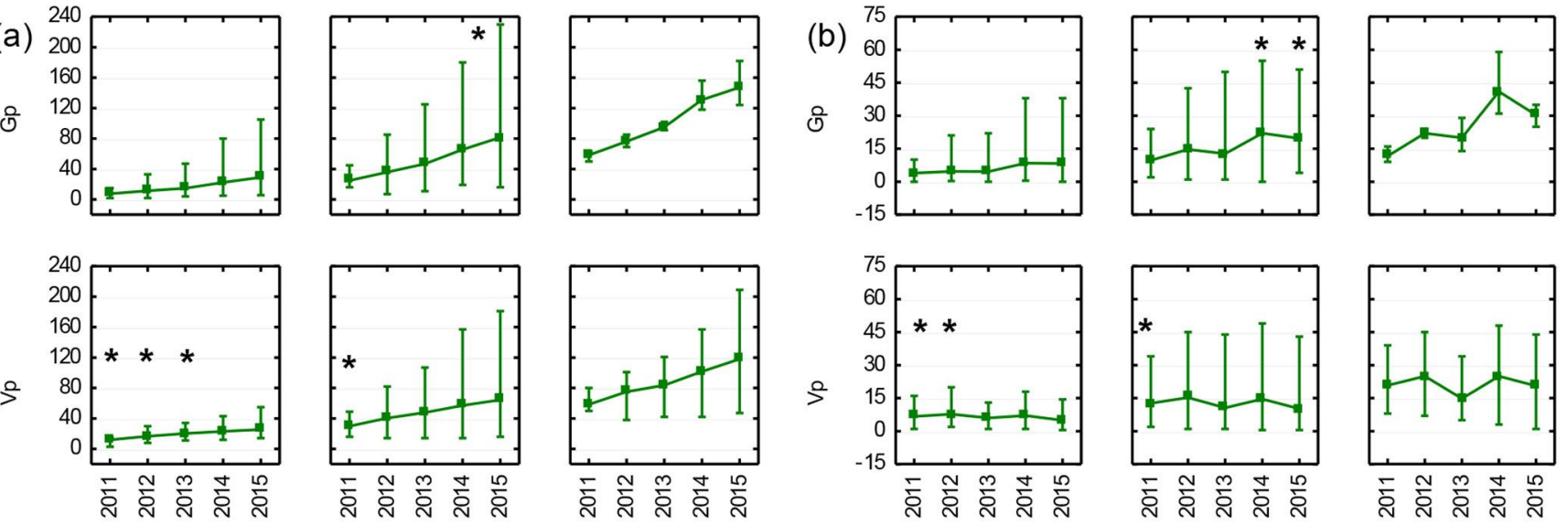

C II
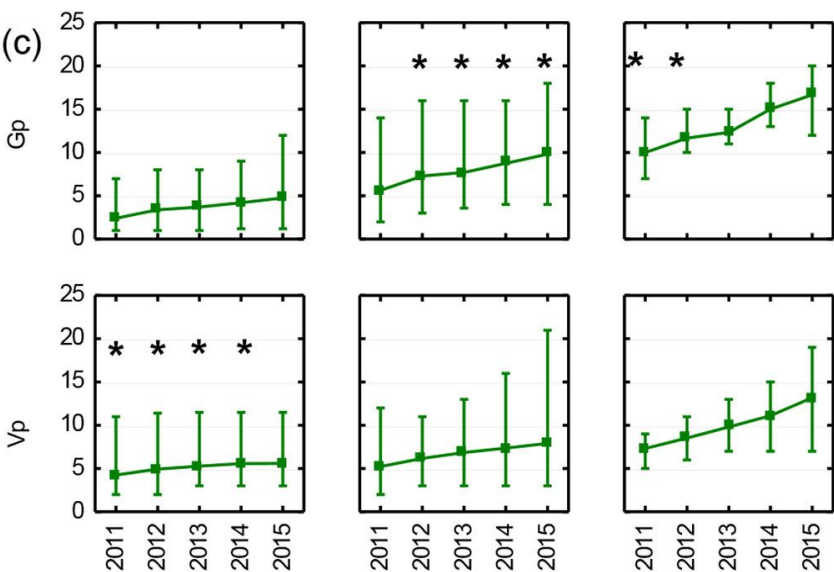

C I

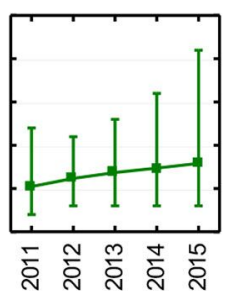

C II

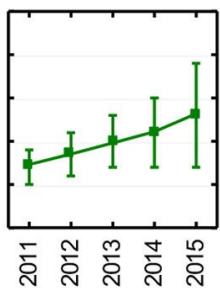

C III

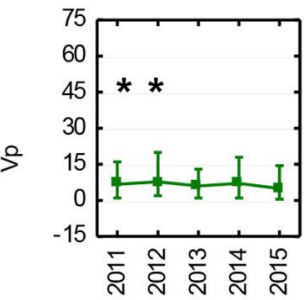

C I

(d)
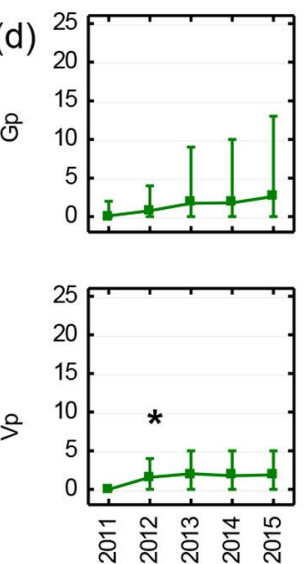

CI

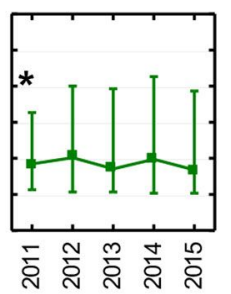

CII
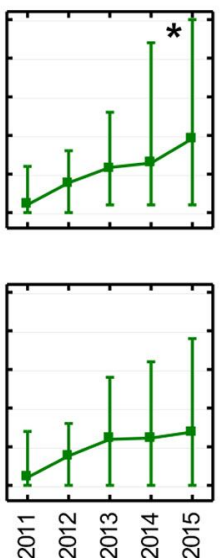

C II

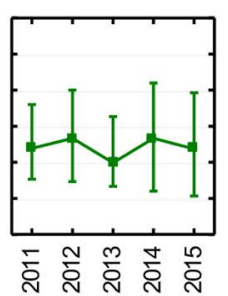

C III
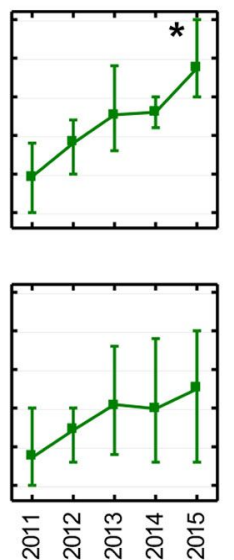

C III

Fig. 6 - Mean (points), minimum and maximum values (vertical lines) of total height (a), annual growth (b), stem diameter (c) and number of branches $(d)$ of generative $(G p)$ and vegetative $(V p)$ recruits of Sorbus torminalis in five subsequent years (2011-2015). Stars denote the significant differences $(p<0.05)$ after $t$-test. Age-development classes by the state for the year 2011. 
individuals, and did not differ from them as for the other characters. CII Individuals were noticeably taller, had higher annual growth and a larger stem diameter than the stem of their vegetative counterparts. $\mathrm{CII}$ and CIII seedlings were also more branching than vegetative individuals (Tab. 3).

Observations of recruits on a year-by-year basis indicated that the largest differences between generative and vegetative individuals emerged in the $\mathrm{Cl}$ and CIl age-development classes. Root suckers, which were larger in the $\mathrm{Cl}$ stage were next overgrown by generative individuals, and these differences persisted in the $\mathrm{Cll}$ and $\mathrm{CIII}$ stages. CIII individuals showed a very dynamic growth regardless of their origin. However, vegetative $\mathrm{CIII}$ individuals were, generally, less uniform than generative ones, as expressed by the greater discrepancy between the minimum and maximum values of annual growth, stem diameter and number of branches (Fig. 6a, Fig. 6b, Fig. 6d).

\section{Discussion}

Our study evaluates the impact of the origin and age of Sorbus torminalis recruits on their survival and growth rate in a natural population of the species. Both research aspects are novel for the wild service tree.

In the study area, the share of recruits originated from seeds and root suckers was very even. It appeared that five-year mortality was clearly higher in the generative progeny when compared to vegetative one. However, it also depended on the age of the offspring. All dead generative individuals were among the youngest seedlings $(\mathrm{Cl})$, while dead vegetative recruits were observed in $\mathrm{Cl}, \mathrm{CII}$ and $\mathrm{CIII}$ classes. The results of our studies also showed that the survival rate of Sorbus torminalis seedlings in the fenced plot is comparable with that that recorded for seedlings grown in cultivation (Sulkowska \& Wojda 2015). This supports the effectiveness of simple conservation activities, such as fencing and partial reducing of competition, on the survival of spontaneous regeneration. The low seedling survival at their earliest years has been previously described for various deciduous trees in the temperate zone (Jones \& Schartitz 1998, Szwagrzyk et al. 2001, Zywiec 2014). Zywiec \& Holeksa (2012) assumed that the Sorbus aucuparia individuals of vegetative origin could have higher survival rate than the seedlings. However, according to their study, the probability of survival of Sorbus aucuparia sprouts increases with age, which was not found in our study.

We found that the main factor affecting the growth of Sorbus torminalis recruits is their age and not their origin. The growth rate increases with height when the direct growth is considered, but subtly decreases when we compare relative growth. This may indicate the importance of a larger pre-existing biomass of recruits in observed growth rate. The role of larger pre-

Tab. 3 - Means and $t$-test results for morphological characters of the generative (Gp) and vegetative progeny (Vp) of Sorbus torminalis in 2011 and 2015. Age-development classes by the state for the year 2011.

\begin{tabular}{|c|c|c|c|c|c|c|c|}
\hline \multirow{2}{*}{ Character } & \multirow{2}{*}{ Class } & \multicolumn{2}{|c|}{2011} & \multirow{2}{*}{$\begin{array}{c}t \text {-test } \\
\text { (p-value) }\end{array}$} & \multicolumn{2}{|c|}{2015} & \multirow{2}{*}{$\begin{array}{c}t \text {-test } \\
(\mathrm{p} \text {-value })\end{array}$} \\
\hline & & Gp & $V p$ & & Gp & $\mathrm{Vp}$ & \\
\hline \multirow{3}{*}{$\begin{array}{l}\text { Total height } \\
(\mathrm{cm})\end{array}$} & $\mathrm{Cl}$ & 7.8 & 12.0 & $<0.001$ & 29.0 & 25.5 & 0.459 \\
\hline & $\mathrm{Cll}$ & 25.0 & 30.1 & 0.001 & 81.5 & 64.5 & 0.007 \\
\hline & CIII & 58.3 & 58.5 & 0.994 & 147.3 & 118.1 & 0.314 \\
\hline \multirow{3}{*}{$\begin{array}{l}\text { Annual } \\
\text { growth }(\mathrm{cm})\end{array}$} & $\mathrm{Cl}$ & 3.9 & 6.7 & $<0.001$ & 8.3 & 4.9 & 0.356 \\
\hline & $\mathrm{CII}$ & 9.7 & 12.6 & 0.013 & 19.7 & 10.2 & $<0.001$ \\
\hline & CIII & 11.7 & 20.8 & 0.082 & 30.3 & 20.5 & 0.256 \\
\hline \multirow{3}{*}{$\begin{array}{l}\text { Stem } \\
\text { diameter } \\
(\mathrm{mm})\end{array}$} & $\mathrm{Cl}$ & 2.4 & 4.3 & $<0.001$ & 4.8 & 5.6 & 0.056 \\
\hline & $\mathrm{CII}$ & 5.6 & 5.2 & 0.259 & 9.8 & 7.9 & $<0.001$ \\
\hline & CIII & 10.0 & 7.3 & 0.065 & 16.7 & 13.2 & 0.249 \\
\hline \multirow[t]{3}{*}{ No. branches } & $\mathrm{Cl}$ & 0.1 & 0.0 & 0.129 & 2.6 & 1.9 & 0.833 \\
\hline & $\mathrm{CII}$ & 1.0 & 1.0 & 0.851 & 9.6 & 6.9 & $<0.001$ \\
\hline & CIII & 4.7 & 3.6 & 0.820 & 18.7 & 12.5 & 0.116 \\
\hline
\end{tabular}

existing biomass in observed superior gross production has been shown for e.g. Robinia pseudoacacia and Ailanthus altissima (Castro-Diez et al. 2014).

Surprisingly, newly established seedlings of $\mathrm{S}$. torminalis showed a very slow growth rate, not exceeding $10 \mathrm{~cm}$ in height after 3 4 years. As a comparison, the average height of 4-year-old seedlings of this species in progeny-provenance plots from two locations in Poland amounted to about 92 $\mathrm{cm}$ (Sulkowska \& Wojda 2015), whereas in Iran the height of 3-year old seedlings was $50 \mathrm{~cm}$ on average (Espahbodi et al. 2008). However, it seems that the significant differences observed in the growth rate of the youngest seedlings (up to about 5-8 years) progressively flattens out during their development. For seedlings from the CIII class $(50-79 \mathrm{~cm})$, the average annual height increments attained ca. $30 \mathrm{~cm}$ in our study. These results are consistent with observations of height increments of young Sorbus torminalis trees (up to 20 years) by other authors (Nicolescu et al. 2009, Schüte 2001, Pyttel et al. 2013). Indeed, the wild service tree can be regarded as a slowgrowing species with shade-tolerant characteristics in the juvenile phase (Pyttel et al. 2013). A recent dendrochronological survey of the species in Poland showed that its mean radial growth is $1.44 \mathrm{~mm}$ year $^{-1}$, and only $1.28 \mathrm{~mm}^{-1}$ year $^{-1}$ for the population at Krzyz Forest District (Cedro 2016). Slow growth rate of forest tree seedlings is commonly observed in natural stands, as a seedling bank is an important element of the reproductive strategy of many tree species (Marks \& Gardescu 1998, Connell \& Green 2000, Bond \& Midgley 2001, Szwagrzyk et al. 2001, Antos et al. 2005, Szymura 2005, Zywiec 2008). In the form of a seedling bank a new generation of trees is waiting for a long time for a canopy gap. When lighting conditions improve, most seedlings significantly accelerate their growth. Some recent studies also revealed that trees with early slow growth lived longer than fast-growing trees (Loehle 1988, Johnson \& Abrahms 2009).
In our study, the impact of the origin of Sorbus torminalis recruits on their growth was noticeably weaker than the impact of the age-development class. The analysis of growth rate showed that, generally, generative recruits have grown faster than vegetative individuals. Also, we found that the origin of recruits had a major effect on annual growth of shoots and a minor effect on the number of branches and diameter of stems. Initially, large-sized vegetative individuals were overgrown by generative individuals over the next four years. More intensive branching in generative recruits results in higher total leaf biomass and photosynthetic area. On the other hand, less dynamic growth of sprouts after four years, together with the higher variability of all analysed growth features may be related to the increasing overcrowding of individuals in a small area, which results directly from the nature of root suckering. As previously mentioned, the studied population was fenced and released from browsing pressure. This treatment allowed us to be sure that the slower growth of sprouts in $\mathrm{CI}$ and $\mathrm{CIII}$ classes was not a consequence of herbivory. According to Savill (1991 after Nicolescu et al. 2009), the root suckers of $\mathrm{S}$. torminalis are more shade tolerant than seedlings and can easily withstand the overshade in the first years. The root suckers grow quickly in height in the first 10-15 years and then their growth is expected to slow down. Schüte (2001) reported that after 6-8 years root suckers are still not independent from the root system of the mother tree. This may explain the observation that suckers or sprouts are less susceptible to stress factors as shade or water deficit (Pietras et al. 2016) and they have faster initial growth compared to seedlings. This finding is consistent with our observations. Also, in case of Robinia pseudoacacia which reproduces both sexually and asexually (Kowarik 1996, Jung et al. 2009, Kurokochi et al. 2010), some studies have shown that new horizontal roots are supplied with photosynthates from the mother plant or ramet for a few years only 
and that resource translocation between neighboring ramets within the same clone ceases after several years (Jung et al. 2009). This might explain the advantage of root sprouts in the initial period of their development.

Generative reproduction can be very important for ensuring the continuity of Sorbus torminalis natural populations, as for the higher shade tolerance of younger seedlings and their faster growth at later stages. As a conservation strategy for the species, the in situ promotion and protection of natural regeneration from seeds should be undertaken (Demesure-Musch \& Oddou-Muratorio 2004, Bednorz 2007, 2009). In recent years, S. torminalis seedlings produced in the nursery have been planted in forest stands in Poland with the aim of increasing their biodiversity and contributing to the protection of this rare species. Although such activities are certainly commendable, in situ conservation measures should not be neglected.

Further studies on the reproductive strategy of Sorbus torminalis in different natural stands should be undertaken to acquire more comprehensive knowledge of this rare and valuable species of European forests.

\section{Acknowledgements}

This study was supported by the Ministry of Science and Higher Education, Warsaw, Poland (statutory funds no 508.641.00). We thank prof. J. Burczyk and Dr. S. Jankowska-Wroblewska (Jan Kazimierz University in Bydgoszcz, Poland) for re-sharing their unpublished molecular data. We are also grateful to J. Zwierzynski, M. Podsiedlik, L. Kaczmarek and J. Bednorz for help with field measurements.

LB planned the research, carried out the field measurements; RN performed the statistical analysis; LB and RN wrote the article.

\section{References}

Antos J, Guest H, Parish R (2005). The tree seedling bank in an ancient montane forest: stress tolerators in a productive habitat. Journal of Ecology 93: 536-543. - doi: 10.1111/j.1365-2745.20 05.00968.x

Bednorz L (2007). Conservation of genetic resources of Sorbus torminalis in Poland. Dendrobiology 58: 3-7. [online] URL: http://agro. icm.edu.pl/agro/element/bwmeta1.element.agr o-article-8ebe0401-9716-4dd8-a1a2-8fc94bobo afc

Bednorz L (2009). Jak chronić jarzab brekinie (Sorbus torminalis) w polskich lasach? [How to protect the wild service tree (Sorbus torminalis) in Polish forests?]. Sylwan 153 5: 354-360. [in Polish]

Bednorz L, Kazmierczak K, Kaczmarek L (2012). Analyses of spatial structure and selected measures of growth of Sorbus torminalis in Forest District Jamy (northern Poland). Dendrobiology 67: 59-65. [online] URL: http://yadda.icm.edu. $\mathrm{pl} /$ yadda/element/bwmeta1.element.agro-2dd3 74c9-f37b-4ac3-89ca-53d9840f1233
Bond WJ, Midgley JJ (2001). Ecology of sprouting in woody plants: the persistence niche. Trends in Ecology and Evolution 16: 45-51. - doi: 10.1016/S0169-5347(00)02033-4

Castro-Diez P, Valle G, González-Muñoz N (2014). Can the life-history strategy explain the success of the exotic trees Ailanthus altissima and Robinia pseudoacacia in Iberian floodplain forests? PLOS ONE 9 (6): e100254. - doi: 10.1371/journal. pone.0100254

Cedro A (2016). Dendrochronologiczna analiza jarzebu brekinii (Sorbus torminalis L.) w Polsce [Dendrochronological analysis of the wild service tree (Sorbus torminalis L.) in Poland]. ZAPOL Sobczyk Spólka Jawna, Szczecin, Poland, pp. 210. [in Polish]

Connell JH, Green PT (2000). Seedling dynamics over thirty-two years in a tropical rain forest tree. Ecology 81: 568-584. - doi: 10.1890/00129658(2000)081[0568:SDOTTY]2.0.CO;2

Demesure-Musch B, Oddou-Muratorio S (2004). EUFORGEN Technical Guidelines for genetic conservation and use for wild service tree (Sorbus torminalis). International Plant Genetic Resources Institute, Rome, Italy, pp. 6. [online] URL: http://books.google.com/books?id=eTnPBK54fkC

Espahbodi K, Mirzaie-Nodoushan H, Tabari M, Akbarinia M, Dehghan-Shuraki $Y$, Jalali SG (2008). Genetic variation in early growth characteristics of two populations of wild service tree (Sorbus torminalis (L.) Crantz) and their interrelationship. Silvae Genetica 57 6: 340-348. - doi: 10.1515/sg-2008-0050

Ewald C, Zander M, Jander A (1994). Die Elsbeere (Sorbus torminalis [L.] Crantz) in Brandenburg [The wild service tree (Sorbus torminalis [L.] (rantz) in Brandenburg]. Der Wald 44: 232-235. [in German]

Hochbichler E (2003). Die Elsbeere (Sorbus torminalis Crantz) im Weinviertel (Niederösterreich) [The wild service tree (Sorbus torminalis Crantz) in Weinviertel (Niederösterreich)]. Forst und Holz 58 21: 647-653. [in German]

Hoebee SE, Menn C, Rotach P, Finkeldey R, Holderegger $R$ (2006). Spatial genetic structure of Sorbus torminalis: the extent of clonal reproduction in natural stands of a rare tree species with a scattered distribution. Forest Ecology and Management 226: 1-8. - doi: 10.1016/j.for eco.2005.12.024

Jankowska-Wroblewska S, Meyza K, Sztupecka E, Kubera I Burczyk J (2016). Clonal structure and high genetic diversity at peripheral populations of Sorbus torminalis (L.) Crantz. iForest 9: 892-900. - doi: 10.3832/ifor1885-009

Johnson SE, Abrahms MD (2009). Age class, longevity and growth rate relationships: protracted growth increases in old trees in the eastern United States. Tree Physiology 29: 13171328. - doi: 10.1093/treephys/tppo68

Jones RH, Schartitz RR (1998). Survival and growth of woody plant seedlings in the understory of floodplain forests in South Carolina. Journal of Ecology 86: 574-587. - doi: 10.1046/j. 1365-2745.1998.00287.x

Jung SC, Matsushita N, Wu BY, Kondo N, Shiraishi A, Hogetsu T (2009). Reproduction of a Robinia pseudoacacia population in a coastal Pinus thunbergii windbreak along the Kujukurihama Coast, Japan. Journal of Forest Research
14: 101-110. - doi: 10.1007/s10310-008-0109-1 Koop H (1987). Vegetative reproduction of trees in some European natural forests. Vegetatio 72 (2): 103-110. [online] URL: http://link.springer. com/article/10.1007/BFoo044840

Kowarik I (1996). Funktionen klonalen Wachs tums von Bäumen bei der Brachflächen-Sukzession unter besonderer Berücksichtigung von Robinia pseudacacia [Functions of clonal growth of trees in the wasteland-succession with special attention of Robinia pseudoacacia]. Verhandlungen der Gesellschaft für Ökologie 26: 173-181. [in German]

Kurokochi H, Toyama K, Hogetsu T (2010). Regeneration of Robinia pseudoacacia riparian forests after clear-cutting along the Chikumagawa River in Japan. Plant Ecology 210 1: 31-41. doi: $10.1007 / \mathrm{s} 11258-010-9735-8$

Loehle C (1988). Tree life history strategies: the role of defenses. Canadian Journal of Forest Research 18 (2): 209-222. - doi: 10.1139/x88-032 Marks PL, Gardescu S (1998). A case study of sugar maple (Acer saccharum) as a forest seedling bank species. Journal of the Torrey Botanical Society 125 (4): 287-296. - doi: 10.2307/299 7242

Müller SV, Ammer C, Nüsslein S (2000). Analyses of stand structure as a tool for silvicultural decisions - a case study in Quercus petrea - Sorbus torminalis stand. Forstwissenschaft Centralblatt 119: 32-42. - doi: 10.1007/BF02769124

Nicolescu VN, Hochbichler E, Coello Gomez J, Ravagni S, Giulietti V (2009). Ecology and silviculture of wild service tree (Sorbus torminalis (L.) Crantz): A literature review. Die Bodenkultur 60 3: 35-44. [online] URL: http://www.re searchgate.net/publication/257633350

Oddou-Muratorio S, Demesure-Musch B, Pelissier R, Gouyon P-H (2004). Impacts of gene flow and logging history on the local genetic structure of a scattered tree species, Sorbus torminalis L. Crantz. Molecular Ecology 13 (12): 3689-3702. - doi: 10.1111/j.1365-294X.2004.0237 3. $x$

Paganova V (2007). Ecology and distribution of Sorbus torminalis (L.) Crantz. in Slovakia. Horticultural Science 34 (4): 138-151. [online] URL: http://81.0.228.28/publicFiles/00500.pdf Pietras J, Stojanovic M, Knott R, Pokorny R (2016). Oak sprouts grow better than seedlings under drought stress. iForest 9: 529-535. - doi: 10.3832/ifor1823-009

Pyttel P, Kunz J, Bauhus J (2013). Growth, regeneration and shade tolerance of the Wild Service Tree (Sorbus torminalis (L.) Crantz) in aged oak coppice forests. Trees 27: 1609-1619. - doi: 10.1007/s00468-013-0908-7

Rasmussen KK, Kollmann J (2004). Poor sexual reproduction on the distribution limit of the rare tree Sorbus torminalis. Acta Oecologica 25: 211-218. - doi: 10.1016/j.actao.2004.02.001 Rasmussen KK, Kollmann J (2007). Genetic diversity, spatial patterns, and growth of root sprouts in a temperate tree at the northern distribution limit. Ecoscience 14: 250-258. - doi: 10.2980/1195-6860(2007)14[250:GDSPAG]2.0.C $0 ; 2$

Rasmussen KK, Kollmann J (2008). Low genetic diversity in small peripheral populations of a rare European tree (Sorbus torminalis) dominated by clonal reproduction. Conservation 
Genetics 9: 1533-1539. - doi: 10.1007/s10592-0079492-y

Rich $\mathrm{T}$, Houston L, Robertson A, Proctor $M$ (2010). Whitebeams, rowans and service trees of Britain and Irland. A monograph of British and Irish Sorbus L. BSBI Handbook no. 14, Botanical Society of the British Isles, London, UK, pp. 229.

Rotach P (2000). Zur Gefährdung seltener Baumarten in der Schweiz: Grundsätzliche Überlegungen, Situationsanalyse und zwei Fallbeispiele [Endangerment of rare tree species in Switzerland: basic considerations, current situation and two examples]. Forest, Snow and Landscape Research 75 (1-2): 267-284. [in German]

Schüte G (2001). Jungendwachstum und Schattentoleranz vegetativer Verjüngungen der Elsbeere (Sorbus torminalis Crantz) [Juvenile growth and shade tolerance of rootsucker regenerations of wild service tree (Sorbus torminalis Crantz). Forst und Holz 56: 11-15. [in German]

Sulkowska MK, Wojda T (2015). Importance of the wild service tree (Sorbus torminalis (L.) Crantz) progeny-provenance trials in ex-situ conservation. Monographs of Botanical Gardens 2: 65-75.

Szwagrzyk J, Szewczyk J, Bodziarczyk J (2001). Dynamics of seedling banks in beech forest: results of a 10-year study on germination, growth and survival. Forest Ecology and Management 141: 237-250. - doi: 10.1016/S0378-1127(00)003327

Szymura TH (2005). Silver fir sapling bank in seminatural stand: individuals architecture and vitality. Forest Ecology and Management 212: 101-108. - doi: 10.1016/j.foreco.2005.03.003
Wos A (2010). Klimat Polski w drugiej polowie XX wieku [Climate of Poland in the second half of XX century]. Wydawnictwo Naukowe UAM, Poznan, pp. 489. [in Polish]

Zywiec M, Holeksa J (2012). Sprouting extends the lifespan of tree species in a seedling bank: 12-year study. Forest Ecology and Management 284: 205-212. - doi: 10.1016/j.foreco.2012.08.007 Zywiec M (2008). The growth rate of rowan (Sorbus aucuparia L.) versus subalpine spruce stand breakdown. Sylwan 4: 38-45.

Zywiec M (2014). Seedling survival under conspecific and heterospecific trees: the initial stages of regeneration of Sorbus aucuparia, a temperate fleshy-fruited pioneer tree. Annales Botanici Fennici 50: 361-371. - doi: 10.5735/085.050.06 11 